\title{
Determinants of Child Poverty in a South African Township: A Case of Boipatong Township
}

\author{
Jabulile Lindiwe Makhalima \\ School of Economic Sciences, \\ North-West University, Vanderbijlpark, South Africa \\ E-mail: jabulile.makhalima@nwu.ac.za \\ Mmapula Brendah Sekatane \\ School of Economic Sciences, \\ North-West University, Vanderbijlpark, South Africa \\ E-mail: brendah.sekatane@nwu.ac.za \\ Steven Henry Dunga \\ School of Economic Sciences, \\ North-West University, Vanderbijlpark, South Africa \\ E-mail: steve.dunga@nwu.ac.za
}

Doi:10.5901/mjss.2014.v5n1p235

\begin{abstract}
Poverty studies have received unprecedented attention in the past decade and there is still a lot of research around poverty measures and efforts to reduce extreme poverty as per the MDG goal number one. Research shows that the most affected groups of people where poverty prevails are women and children. Child poverty is considered to be one of the main causes of chronic poverty, and its eradication stands to be a shared goal worldwide. The study investigates the possible determinants of child poverty in the Boipatong Township. A logistical regression is used to investigate the effects of the household's total income, employment status, age, of the household head, the number of people in the household and gender of head of household on child poverty. The results of the study indicate that employment status of the head of the household, number of people living in the household and total income of the household are significant determinants of child poverty status in Boipatong.
\end{abstract}

Keywords: Poverty, Child poverty, Boipatong, Children, Poor, Non-poor, Employment, Head of house

\section{Introduction}

Poverty studies have received unprecedented attention in the past decade. There have been efforts to understand poverty in order to find ways to eradicate extreme forms of the same. Studies by World Bank such as Dollar and Kraay (2000; 2001; 2002) revealed the importance of growth in reducing poverty. Other studies looked at the distributional effects and how poverty reduction measures respond differently to different interventions (Bourguignon, 2003; Kakwani \& Pernia, 2000). There is still a lot of research around poverty measures and efforts to reduce extreme poverty as per the MDG goal number one. Research done on poverty shows that the most affected groups of people where poverty prevails are women and children (UNICEF, 2006).

The eradication of Childhood poverty, which is one of the contributing causes of chronic poverty, is considered to be a common goal amongst countries worldwide (Barrientos \& DeJong, 2004: 9). Child poverty is also highly manifested in malnutrition especially in children under five years of age (UNICEF, 2006). Malnutrition can be damaging in the first few years of a child's life. The root cause of malnutrition in early childhood is complex with various fundamental contributors which are aligned to lack of food, insufficient breastfeeding as the mothers are malnourished insufficient and lack of decent education, poor health, absence of adult care and violence have a negative impact on children's physical, cognitive and psychological development. The consequences thereafter are often irreversible and life threatening (Bhutta \& Psaki, 2011:3) due to their upbringing, these poor children will experience difficulties in securing good employment and 
also enjoy long healthy lifestyles as adults. Furthermore, these children are likely to fail as parents to ensure that their children have the best education and access to the necessary resources to better themselves (Lewit, Terman \& Berhman, 1997).

This study investigates the determinants of child poverty in a South African Township of Boipatong. The aim of the study is to understand the household characteristics that are associated with child poverty. The study concentrates on the characteristics of the head of the household which are considered to have an effect on the poverty status of the household and consequently on the child poverty status. Some of the household idiosyncrasies to be considered includes the gender of head of household, the employment status of the head of household, education level of the head of household and household total income among other things. The rest of the paper is organised as follows; section 2 reviews the literature on poverty in general and child poverty in particular. Section 3 presents the methodology used in the data collection process and the data analysis. The logistic regression used to investigate on the determinants of child poverty is also specified in this section. Section 4 presents the results and discussion, and section 5 is a conclusion.

\section{Literature review of the child poverty Measures}

Studies on poverty in South Africa which were conducted before democracy have to a large degree ignored the incidence of child poverty. The Carnegie Inquiry which looked at White poverty was first conducted in 1928. Child poverty which was a White's only study was limited to only health and educational conditions of White children. Child poverty studies amongst Black children were never done. The 1980's saw second Carnegie Inquiry look into poverty dynamics but nothing on the child poverty component. The end of the Apartheid era allowed researchers such the United Nations Children's Fund (UNICEF) and the Convention on the Rights (CRC) to do research on women and children in South Africa (Barnes, 2009:3).

Child poverty is an unsettling situation whereby a human being experiences poverty at an early age. The situation is particular in a sense that once a child experiences the poverty, its likelihood of remaining there is quite high even living it right through to adulthood. This may lead to stunting as well as psychological trauma which may affect a person for the rest of their lives. The main international legal instrument on children's rights is the CRC where South Africa is a member state. Child poverty can therefore be defined as violation of the rights protected by the CRC (UNICEF, 2006:2).

The task of determining child poverty is cumbersome and this is due to the fact that the concept itself is not easy to define and that few methodologies exist for measuring child poverty (Mirugi-Mukundi, 2009:3). According to Statistics South Africa (Stats SA, 2011:9), approximately 15812268 children form part of the South African population. Whereas the extent of child poverty is a great cause of concern, it is almost impossible to disregard the prevalence of child poverty and its particular impact on children (Mirugi-Mukundi, 2009:3). The child poverty situation is different from that of adults and therefore cannot be compared. A child's encounter of poverty has more urgent needs which orthodox anti-poverty strategies do not address. The causes and effects of child poverty may have a lasting or even a permanent effect on a child's future (Munijin, Delamonica, Gonzalez \& Davidzuik, 2006:483). This study aims at reviewing the poverty measures used to determine child poverty in general and a deliberate focus on South Africa in particular. This is done with an aim of unveiling the shortcoming that can exist when child poverty is not clearly understood hence rendering the intervening policies ineffective. The remainder of the paper is organised as follows; section 2 looks at the literature on poverty measures and how child poverty is deciphered from the same. Section 3 discusses the methodology in the review of the child poverty measures. Section 4 presents an in-depth discussion of the child poverty measures or lack thereof and section 5 concludes the paper.

\section{Methodology}

This paper uses an equivalence scale adopted from OECD to come up with a child poverty line. The OECD equivalence scale is however adapted to a scale proposed by Steak et al. (2008) by also taking into account suggestions made by Streak et al. (2008) in the sensitivity of child poverty in response to changes in adult equivalence scales, the study adopts an equivalence scale that take into account age differences.

\subsection{Data}

The paper uses data that was collected in Boipatong Township in South Africa. In the survey, 300 questionnaires were administered to head of households by 2 field workers in September 2013. Households were randomly selected from a 
population of Boipatong. Maps were obtained from Boipatong to help with the sampling. The survey collected information of household income and expenditure to be used as a welfare measure. Household income was arrived at from wages or salaries for working households and also from the different grants households in South Africa access.

\subsection{Measuring child poverty}

STATS SA reported the adult poverty line for South Africa to be at R507 in 2008 (STATS SA, 2008:26), the study has therefore adjusted the poverty line to R520 taking to account the inflation rates in the years between 2008 to 2013. An adult equivalence scale (AES) which gives the adult a 1 as a benchmark was then used to come up with the weight for different age groups. The AES is a tool which is designed to work through the differences, and to ultimately make a transformation from household level to individual level welfare (Streak, Yu \& van der Berg, 2008:185).

The general approach for using the AES is to use the form introduced by Cutler and Katz (1992) namely

$$
A E=(A+\alpha K)^{\beta}
$$

Where: $A E$ refers to the adult equivalent $A$, represents the number of adults in the household $K$ represents the number of children a adjusts for age equivalences $\beta$ adjusts for economies of scale. The household size element that the AES addresses is that bigger households need larger incomes where income is used as a measure or expenditure where expenditure is used unlike smaller households in order to obtain the same level of welfare. The AES thus gives allowance to analyse the determinants of child poverty through child poverty measurement (Streak et al. 2008:185).

Streak et al (2008:7) points out that there is no universal and scientifically determined true value for $a$. The true costs vary from country to country and are probably different for children of different ages and even gender. In this study the economies of scale component in the Cutler and Katz formulation is left out, only the adult equalisation is considered for different age group. The following poverty lines were therefore arrived at using 18 years as the cut off point for children.

Table 1: Poverty Lines

\begin{tabular}{|l|c|l|}
\hline Age & Equivalence scale & Poverty line \\
\hline Below 18 years & $\alpha=0.8$ & 416 \\
\hline 18 and above & $\alpha=1$ & 520 \\
\hline
\end{tabular}

Using the poverty line above, a household poverty line was arrived at, which was different for each household depending on composition. Children from poor household were then counted to be poor to arrive at the child poverty rate in the sample. Out of the 300 households that were included in the survey, there were 265 children and out of the 265 children 122 were from poor household making the child poverty rate to be $46 \%$. This poverty rate is higher compared to the household poverty rate which was found to be at $39 \%$. Table2 and 3 below summarises the child poverty measure and the household poverty measure from the data. 
Table 2: Household Poverty Status

\begin{tabular}{|l|l|l|l|l|l|}
\hline \multicolumn{2}{|c|}{} & Frequency & Percent & Valid Percent & $\begin{array}{l}\text { Cumulative } \\
\text { Percent }\end{array}$ \\
\hline \multirow{3}{*}{ Valid } & non poor Household & 183 & 61.0 & 61.0 & 61.0 \\
\cline { 2 - 6 } & poor Household & 117 & 39.0 & 39.0 & 100.0 \\
\cline { 2 - 6 } & Total & 300 & 100.0 & 100.0 & \\
\hline
\end{tabular}

Table 3: Child Poverty Status

\begin{tabular}{|l|l|l|l|l|l|}
\hline \multicolumn{2}{|l|}{ Child poverty status } & Frequency & Percent & Valid Percent & $\begin{array}{l}\text { Cumulative } \\
\text { Percent }\end{array}$ \\
\hline \multirow{3}{*}{ Valid } & $\begin{array}{l}\text { non poor } \\
\text { children }\end{array}$ & 143 & 54.0 & 54.0 & 54.0 \\
\cline { 2 - 6 } & poor children & 122 & 46.0 & 46.0 & 100.0 \\
\cline { 2 - 6 } & Total & 265 & 100.0 & 100.0 & \\
\hline
\end{tabular}

\subsection{Determinants of child poverty}

To understand the scenario of poor children in the townships, the study moves a step further to investigate on the household characteristic of the head of the poor household where the poor children come from. A regression analysis with poverty status of the child as a dependent variable is used being regressed by household head characteristics.

\subsubsection{Logistic regression model}

First, a dichotomous variable indicating whether a child is poor or not is defined as follows;

$$
\text { CPS }\left\{\begin{array}{l}
1 \text { if the child is poor } \\
0 \text { if the child is not poor }
\end{array}\right.
$$

Where CPS represents the child poverty status. Adopting from Achia et al. (2010) age, household size, education level of the household head and gender of the head of household are used as determinants as follows;

$\operatorname{logit}(P)=\left(\frac{p}{1-p}\right)=\beta_{0}+\beta_{1} X_{1}+\beta_{2} X_{2}+\beta_{3} X_{3}+\beta_{4} X_{4}+\beta_{5} X_{5}+\beta_{6} X_{6}+\varepsilon \ldots$

Where $X_{1 \ldots 6}$ represent the determinants of child poverty namely, Age, gender where 1 is for female 0 is for male, household income, employment status, and number of people in the household. Coefficients $p$ is the probability that the child is poor.

\section{Results and Discussion}

This section of the study presents the descriptives of the variables that are considered as the determinants of child poverty, and also results of the logistic regression are presented and discussed.

\subsection{Descriptives}

The table below shows the relationship between child poverty and gender of household head. The Pearson Chi2 shows that there is a significant relationship between the gender of the head of household and the poverty status of the child. 
The table 4 below shows that there are more poor children in female headed household as compared to male headed households.

Table 4: Relationship between gender and Child poverty

\begin{tabular}{|c|c|c|c|c|}
\hline \multicolumn{5}{|c|}{ Gender Head * Child poverty status Cross tabulation } \\
\hline \multicolumn{5}{|c|}{ Count } \\
\hline & & \multicolumn{2}{|c|}{ Child poverty status } & \multirow[t]{2}{*}{ Total } \\
\hline & & non poor children & poor children & \\
\hline \multirow[t]{2}{*}{ Gender Head } & males & $\begin{array}{l}77 \\
69.9 \%\end{array}$ & $\begin{array}{l}44 \\
30.1 \%\end{array}$ & 121 \\
\hline & female & $\begin{array}{l}69 \\
53.5 \%\end{array}$ & $\begin{array}{l}78 \\
46.5 \%\end{array}$ & 147 \\
\hline \multicolumn{2}{|l|}{ Total } & 146 & 122 & 268 \\
\hline
\end{tabular}

Figure 1: Employment Status

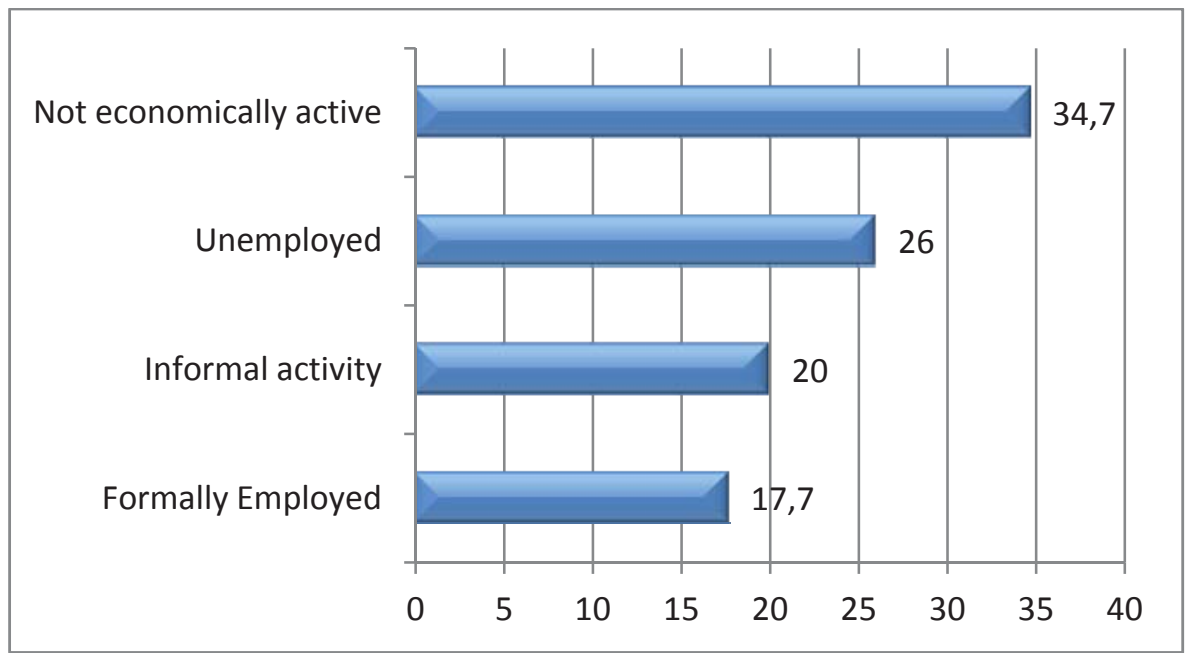

Figure 1 above presents the distribution of employment status of heads of households. $34.7 \%$ of the heads of households were not economically active. Only $17.7 \%$ of the head of households were formally employed. The Pearson chi2 test shows that there is a significant relationship between employment status and child poverty with a p-value of 0.000 .

Table 5: Relationship between Employment Status and Child poverty

\begin{tabular}{|c|c|c|c|c|}
\hline \multicolumn{5}{|c|}{ Employment status * Child poverty status Cross tabulation } \\
\hline & & \multicolumn{2}{|c|}{ Child poverty status } & \multirow[t]{2}{*}{ Total } \\
\hline & & non poor children & poor children & \\
\hline \multirow[t]{4}{*}{ Employment status } & Formally employed & $93.3 \%$ & $5.7 \%)$ & $100 \%$ \\
\hline & Informal activity & $(91.7 \%)$ & $(8.3 \%)$ & $100 \%$ \\
\hline & Unemployed & $(21.8 \%)$ & $(7.8 \%)$ & $100 \%$ \\
\hline & Not economically active & $(55.8 \%)$ & $(44.2 \%)$ & $100 \%$ \\
\hline \multicolumn{2}{|l|}{ Total } & 146 & 122 & 268 \\
\hline
\end{tabular}


Table 5 shows the relationship between employment status and poverty. As was expected there is a significant relationship between the two. The results in table 5 shows that most poor children where in the households where the head was not economically active, with the poverty rate of $44 \%$. For the children from households whose head was formally employed only $5.7 \%$ were found to be poor. Children living in households where the head of the household are involved in the informal sector of employment made up $91.7 \%$ of the population compared to $8.3 \%$ of the children from poor families. This might imply that the informal sector of employment is contributing to poverty alleviation.

\subsection{Regression Results}

Results of the logistic regression (1) are reported in table 6. The coefficient of gender variable of the head of household is positive which means that children from female-headed households have a higher probability of being poor as compared to their counterparts in the male-headed households. Total income is found to be a significant determinant of poverty status with a p-value of .000 . It also has a negative coefficient implying that with an increase in income, there is a reduced probability of being poor. The number of people in the household is also significant in determining child poverty status with a p-value of .001 which is significant at $1 \%$ significant level. The number of people in the household has a positive coefficient which means that the larger the household size, the higher the probability of the children in those households to be poor.

Table 6: Determinants of child poverty

\begin{tabular}{|c|c|c|c|c|c|c|c|}
\hline \multicolumn{8}{|c|}{ Variables in the Equation } \\
\hline & & $B$ & S.E. & Wald & df & Sig. & $\operatorname{Exp}(B)$ \\
\hline \multirow[t]{6}{*}{ Step $1^{a}$} & Gender of head & .577 & .391 & 2.178 & 1 & .140 & 1.781 \\
\hline & $\begin{array}{l}\text { number of people in the } \\
\text { household }\end{array}$ & .396 & .119 & 11.162 & 1 & .001 & 1.486 \\
\hline & Age & -.006 & 016 & 151 & 1 & 698 & .994 \\
\hline & Total income & -.003 & .000 & 62.163 & 1 & .000 & .997 \\
\hline & Employment status & -2.055 & 1.025 & 4.017 & 1 & .045 & .128 \\
\hline & Constant & 3.556 & 1.223 & 8.454 & 1 & .004 & 35.008 \\
\hline
\end{tabular}

Age of the head of household has a negative coefficient implying that the older the head of household, the lower the probability of being poor. Although the p-value is not significant, the sign of the coefficient agrees with theory since age correlates with experience and a study by (DeNavas-Walt, Proctor \& Smith, 2012) also found lower poverty rates amongst older people in the US. People aged 65 and above had a poverty rate of $9.1 \%$ whereas younger people aged 18 and below had a poverty rate of $34.6 \%$. The employment status variable has a negative coefficient implying that those who are employed in the formal sector have a lower probability of being poor. This may imply that the formal sector of employment is more reliable and a good strategy of poverty alleviation (ILO, 2008).

\section{Conclusion}

The study was set to investigate on the determinants of child poverty in Boipatong Township. The results of the study indicate that employment status of the head of the household; number of people living in the household and total income of the household is significant determinants of child poverty status in Boipatong. Under employment status, the study discovered that formal employment was associated with lower levels of poverty and also that the probability of being poor was lower if one was employed formally. This may imply that policies that are aimed at dealing with poverty and child poverty in particular should consider ways of creating formal employment for people in the townships. The negative relationship between age and poverty may imply the order people have more sources of income. This income could be from old age grants or from pensions. 


\section{References}

Aigbokhan, B. E. (2008). Growth, Inequality and Poverty in Nigeria. Addis Ababa, Ethiopia: United Nations Economic Commission for Africa (UNECA).

Barrientos, A., \& DeJong, J. (2004). Child poverty and cash transfers. Child Poverty Research Centre.

Bhutta, Z.; Psaki, S. (2011). Household food insecurity and nutritional status in children: Results from an eight country study.

Bourguignon, F. (2000). The pace of economic growth and poverty reduction. TheWorld Bank and Delta, Paris).

Bourguignon, F. (2003). The growth elasticity of poverty reduction: explaining heterogeneity across countries and time periods. World Bank working paper.

Bourguignon, F. (2004, march). The poverty- growth- inequality triangle. Indian Council for research on international economic relations, new Delhi workingg paper 125.

DeNavas-Walt, C., Proctor, B. D., \& Smith, J. C. (2012). Income, Poverty, and health Insurance coverage in the United states. Washington DC: US Government.

ILO. (2008). Promotion of rural employment for poverty reduction. Geneva: International Labour Office.

Kakwani, N. (1993, June). Poverty and economic and poverty growth with application to cote d'Ivoire. Review of Income and Wealth, 39(2), 121-139.

Kakwani, N., \& Pernia, E. (2000). What is pro-poor growth? Asian development Review, 18(1), 1-16.

Lewit, E. M., Terman, D., \& Berhman, R. (1997). Children and Poverty: Analysis and Recommendations. Children and Poverty, 7, 4-24.

Mirugi-Mukundi., G. 2009. Realising the social security rights of children in South Africa with particular reference to child support grants. Research report written for the Socio-Economic Rights project of the community Law centre

STATSSA. (2008). Measuring poverty in South Africa, Methodological report on the development of the poverty lines for statistical reporting. Pretoria: Statistics South Africa.

STATS SA. 2011. Midyear population estimate. [Web:] http://www.statssa.gov.za/publications/P0302/P03022011.pdf (Date of access: 20 Aug. 2012).

Streak,J.C.,YU,D. \& van der Berg,S. 2008. Measuring child poverty in South Africa: Sensitivity to the choice of the equivalence Scale and an updated profile. Social Indicators Research. Vol 94 No. 2. 188-201.

UNICEF. 2006. Childhood poverty in Mozambique: A situation and trend analysis summary. [Web:] http://www.unicef.org/media/files/Final_SITAN_English_summary.pdf (Date of access: 01Aug. 2012).

UNICEF. (2006). UNICEF. Retrieved November 20, 2013, from UNICEF Domincan Republic: http://www.unicef.org/republicadominicana/english/survival_development_12567.htm

World hunger, 2013. world hunger poverty facts and statistics.

http://www.worldhunger.org/articles/Learn/world\%20hunger\%20facts\%202002.htm 
